\title{
Preliminary dragonfly (Odonata) species list from the Pampa biome in Rio Grande do Sul, Brazil, with ecological notes for 19 new records for the State
}

\author{
Samuel Renner ${ }^{1 *}$, Eduardo Périco ${ }^{I}$, Gerson Júnior Ely ${ }^{I}$ \& Göran Sahlén ${ }^{2}$ \\ ${ }^{1}$ Universidade do Vale do Taquari, Laboratório de Ecologia e Evolução, Rua Avelino Talini, 171, \\ Bairro Universitário, 95900-000 Lajeado, RS, Brazil \\ ${ }^{2}$ Halmstad University, Ecology and Environmental Science, RLAS, P.O. Box 823, 30118 Halmstad, Sweden \\ *Corresponding author: Samuel Renner, e-mail: samuelrenner@hotmail.com
}

RENNER, S., PÉRICO, E., ELY, G. J., SAHLÉN, G. Preliminary dragonfly (Odonata) species list from the Pampa biome in Rio Grande do Sul, Brazil, with ecological notes for 19 new records for the State. Biota Neotropica. 17(4): e20170374. http://dx.doi.org/10.1590/1676-0611-BN-2017-0374

\begin{abstract}
An inventory of Odonata was carried out in the southern half of the state of Rio Grande do Sul, Brazil, in the Pampa biome. Originally, this biogeographical region was covered mostly by open fields and grassland, with sections of higher vegetation surrounding water bodies and rocky hills. Today the landscape is fragmented due to agricultural activities, mainly cattle farming, rice crops and forest plantations. Our survey was conducted in three municipalities from this region, between March 2015 and April 2016. Aiming at a general overview of the species composition, our sampling sites were selected on a wide basis, including lakes, bogs, temporary water bodies, small streams and river sections. Eighty two species of Odonata were collected comprising 40 genera and seven families. The dominant families were Libellulidae (56,1\%), Coenagrionidae (24,5\%) and Aeshnidae (7,3\%). We found a diverse odonate assemblage, adding 19 new species records for the state of Rio Grande do Sul.
\end{abstract}

Keywords: Anthropogenic threats, ecology, grassland, Neotropics, southern fields.

\section{Lista preliminar de libélulas (Odonata) do Bioma Pampa no Rio Grande do Sul, Brasil, com notas ecológicas para 19 novos registros para o estado}

\begin{abstract}
Resumo: Um inventário de Odonata foi desenvolvido na metade Sul do estado do Rio Grande do Sul, Brasil, no Bioma Pampa. Originalmente, esta região biogeográfica era coberta principalmente por campos abertos e pastagens, com seções de vegetação mais alta nas imediações de corpos d'água e elevações rochosas. Atualmente a paisagem se encontra fragmentada devido a atividade agrícola, entre as principais, a criação de gado, cultivo de arroz e silvicultura. A pesquisa foi desenvolvida em três municípios da região, entre Março de 2015 e Abril de 2016. Buscando uma visão geral da composição de espécies, os locais de amostragem selecionados incluíram lagos, banhados, corpos d'água temporários e seções de rio. Oitenta e duas espécies foram coletadas compreendendo 40 gêneros e 7 famílias. As famílias dominantes foram Libellulidae $(55,1 \%)$, Coenagrionidae $(24,5 \%)$ e Aeshnidae $(7,3 \%)$. Nós encontramos uma grande diversidade nas comunidades de Odonata, adicionando 19 novos registros de espécies para o estado do Rio Grande do Sul.
\end{abstract}

Palavras-chave: Ameaças antropogênicas, ecologia, pastagens, região neotropical, campos sulinos.

\section{Introduction}

One of the biggest problems towards conservation measures is the lack of knowledge on species distribution, scientifically known as the Wallacean shortfall (Cardoso et al. 2009). Jetz et al. (2012) stated that even when looking at the best known species, knowledge on their occurrence is substantially lower than the amount of available information of other important environmental variables. Insects is the least known group concerning their distribution, mostly due to their high species richness, lack of taxonomic expertise and lack of sampling (Diniz-Filho et al. 2010). In the Neotropical region, and specifically in Brazil, there are still whole biomes which are almost unknown regarding insects (Oliveira et al. 2017). An example is the Pampa biome: extending from the southern half of the state of Rio Grande do Sul (29. S), southwards through the whole Uruguayan territory and within Argentina to the temperate
Patagonian steppes, and ending at $39^{\circ} \mathrm{S}$ (Roig \& Flores 2001). It covers only around $2 \%$ of the Brazilian territory but more than $63 \%$ of the Rio Grande do Sul State area (IBGE 2016). Although scarce, data from this region has proven high diversity and high levels of endemism, at least regarding the flora (MMA 2002, Behling et al. 2004). The Pampa is under extreme pressure from several human activities such as agriculture, cattle farming, and forestry by the conversion of grasslands into extensive plantations of Eucalyptus, Pinus and Acacia (Bencke 2009, Overbeck et al. 2009, Roesch et al. 2009). Official government data from 2008 , shows that only $36 \%$ of the original vegetation remains in a fragmented mosaic (MMA 2009). In Brazil, the officially protected areas of the Pampa grasslands cover only about $0.5 \%$ of the total biome, thus, more actions are needed to recover and preserve this threatened environment (Overbeck et al. 2009). For conservation purposes, 
information on species diversity becomes more relevant every day, as well as knowledge on range of distribution (Oliveira et al. 2017). Knowing where species occur and their abundance is fundamental for setting up conservation priorities and red listing. Making information available to scientists and the public is also central to overcome the prevailing lack of distribution knowledge (Jetz et al. 2012). Thus, inventories can provide and improve ongoing and future management efforts (Lewis 2006). Concise information is since long needed for biologists and decision makers to prioritize specific areas for the preservation of biodiversity (Kerr et al. 2000). The Odonata fauna in Brazil is moderately known in terms of species occurrence and distribution: only $29 \%$ of the country's territory is adequately surveyed, according to De Marco \& Vianna (2005), but this number is probably outdated. For the southeast and central regions several species lists are available (e.g., Costa et al. 2000, Costa \& Oldrini 2005, Anjos-Santos \& Costa 2006, Calvão et al. 2014, Bedê et al. 2015), while in the southern part of Brazil these studies are more scarce, the most recently published are Kittel \& Engels (2014) and Renner et al. (2015, 2016a, 2016b), which were all conducted in the Atlantic Forest biome. Thus, we were motivated to increase the knowledge of species occurrence to the Pampa biome, the southernmost part of Brazil, where no survey of Odonata has previously been made.

\section{Material and Methods}

\section{Study area}

We sampled 63 localities distributed in four municipalities: Alegrete (AL, N = 10), Manoel Viana (MV, N =9), Santana da Boa Vista (SB, N = 8) and São Francisco de Assis ( $\mathrm{SF}, \mathrm{N}=36$ ); within two different regions ( 1 and 2 ) of the Pampa biome (Figure 1). In total, the three municipality areas encompass more than $13,000,000 \mathrm{~km}^{2}$ (IBGE 2016). The climate is Temperate (Cfb Köppen), with mean annual temperatures between $13^{\circ} \mathrm{C}$ and $17^{\circ} \mathrm{C}$ and altitudes from 50 to $200 \mathrm{~m}$ a.s.l. Annual precipitation mean is between 1,200 and 1,600 mm (INPE 2014). Our sites were distributed among several types of standing and running water including all types of habitats that could be considered to be used as reproduction sites for Odonata. We included small temporary pools or flooding areas, perennial waters such as bogs, swamps, ponds, lakes and rivers of various sizes. These sites included Rivers/streams $(N=27)$, Lakes $(N=18)$ and Temporary waters $(N=18)$, see below.

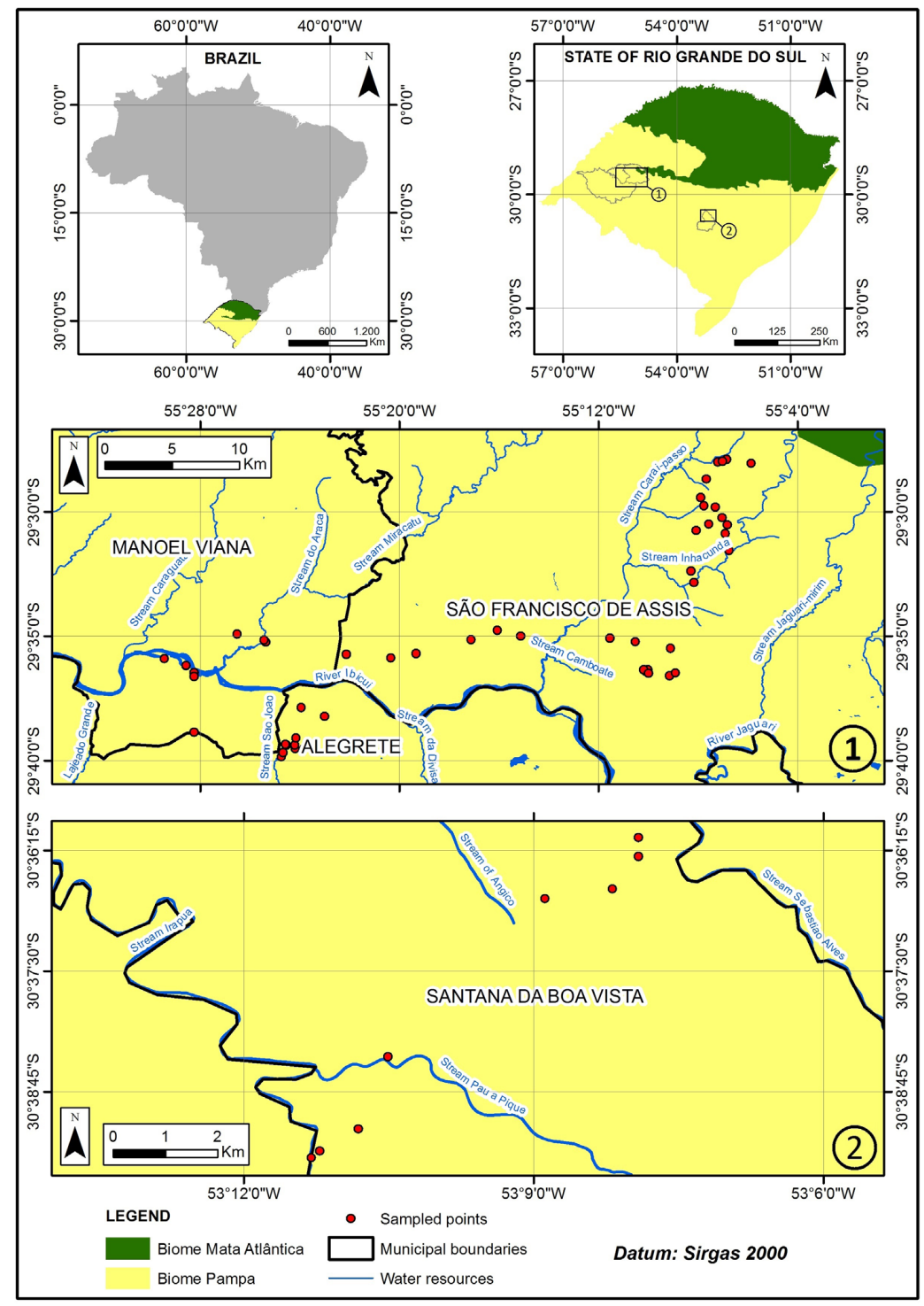

FIGURE 1: Map of Brazil and the Pampa biome domain in Rio Grande do Sul, rectangular insets from the two sampling regions (1 and 2), red dots marking the sampling sites. 


\section{Data collection}

We sampled adult dragonflies from March 2015 to May 2016, the majority of the sampling sites were visited four times during this period, excluding winter due to the lack of activity of adult Odonata in the low temperatures (below $0^{\circ} \mathrm{C}$ ) during that season. Other sites were visited only once, e.g. temporary water and flooded areas. The sampling method followed Renner et al. (2015): hand-held insect nets by a team of two people, in sunny days, during the peak time of Odonata activity (between 09:00 h to 16:00 h). Each site was sampled during 30 minutes, by walking the edge and marginal zones, the distances walked were dependent on the size and type of waterbodies, varying from ca. 50 to $250 \mathrm{~m}$ perimeters. We focused on adults only, since the majority of the larvae are still unknown (e.g., Garrison et al. 2006). Adults are often dispersing long distances (Corbet 1999), and we expect that some of our specimens might therefore derive from other regions. Our aim, however, was not to discern vagrants from reproducing species, but to get an account of species present in the area.

All specimens collected were preserved in $96 \%$ ethanol, and later determined to species level according to Garrison et al. (2006, 2010), Heckman $(2006,2010)$ and Lencioni (2006); species data were compared to the original species descriptions if needed and difficult species were kindly identified with help from Dr. R. W. Garrison, Sacramento, CA, U.S.A. For systematic classification, we followed Dijkstra et al. (2013, 2014). After identification, the specimens were deposited in the Museu de Ciências Naturais da Univates, Lajeado, Rio Grande do Sul, Brazil (MCNU). The collection authorization process was issued by ICMBio, under the number 50624-1. Beyond the municipalities abbreviations (mentioned above), we used the official abbreviations for the Brazilian states, as follows: AM (Amazonas) BA (Bahia), CE (Ceará), ES (Espírito Santo), GO (Goiás), MG (Minas Gerais), MS (Mato Grosso do Sul), MT (Mato Grosso), PA (Pará), PI (Piauí), PR (Paraná), RJ (Rio de Janeiro), RS (Rio Grande do Sul), SC (Santa Catarina), SE (Sergipe), SP (São Paulo) and TO (Tocantins).

To quantify our sampling effort, we choose to present a rarefaction curve (Mao tau) and the Jakkinfe 1 estimator. It is a general statistical technique for reducing the bias of an estimator by removing subsets of the data and recalculating the estimator with the reduced sample. Specifically, Jackknife1 depends only on the uniques (species found in only one sample) because the richness estimated is changed only when a sample that contains one of these species is deleted from a subset of samples (Gotelli \& Colwell, 2011). We also quantified our sampling effort by using a Jackknife estimation of total species richness according to Smith \& van Belle (1984).

\section{Results}

\section{Sampling sites}

We sampled many different environments ranging from temporary water bodies (small sites) to big river sections. Some of these places were in good environmental conditions, only marginally affected by human disturbances, and notable by the presence of species considered rare by us. These were small erosion sites with temporary water flow, small streamlets/swamps where cold and clear water was flowing from the underground (Figure 2a), temporary flooding zones at a major river (Figure 2b) and also swampy areas with varied and well vegetated edge zones (Figure 2c). Most of the present threats to such unique environments are related to the expansion of forestry practices, which are growing notably and quickly in the regions where the studies took place.

\section{Species List}

Eighty-two species belonging to 40 genera and seven families were collected in the three municipalities (Table 1). Seven specimens, newly emerged males and/or females, were impossible to determine to species level; so these were classified as "sp.". Among these we found two specimens of an undescribed species belonging to the family Coenagrionidae. This species is currently under description by Dr. J. Muzón (La Plata, Argentina, personal communication), and no further information is therefore given here. Libellulidae was the dominant family $(56,1 \%, \mathrm{~N}=46)$ followed by Coenagrionidae $(24,5 \%, 20)$ and, Aeshnidae $(7,3 \%, 6)$, as shown in Table 2. The richest genus was Erythrodiplax, represented by eight species, this genus was also the most abundant in all seasons, occurring in virtually all sampling sites along with Pantala flavescens Fabricius, 1798, a known migratory and widely distributed disperser (Troast et al. 2016). Some species occurred only once (uniques) in this study and were considered regionally rare, for example: Minagrion waltheri Selys, 1876, Brechmorhoga nubecula Rambur, 1842, Macrothemis lutea Calvert, 1909 and Dasythemis venosa Burmeister, 1839. The rarefaction curve, which was based on the sampling events data, gave us a view of the sampling effectiveness of this study (Figure 3), tending to reach its asymptote. According to Smith \& van Belle (1984) calculations using Jackknife as estimator, we expect 101 species to occur in the region, meaning we reached $81 \%$ of the total estimated diversity.

\section{New records}

Excluding the single undescribed species, we found 19 new records for the Rio Grande do Sul State; some of these species we considered rare and some seem to be well distributed in South America. Here we present some habitat preferences and ecological aspects of these species, based on the literature found and on our field observations.
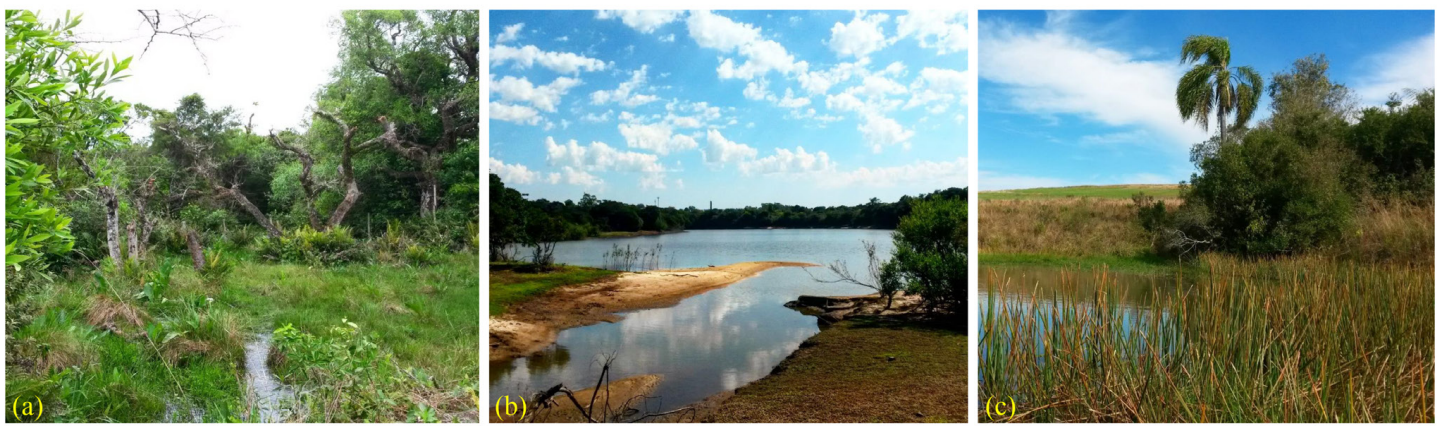

FIGURE 2: Some of the sampling sites which were remarkable by good environmental conditions: (a) Swampy area, with slowly flowing clear water in SF; (b) Flooding area near to Ibicuí River, MV; (c) Swamp close to a forested edge zone in SB. 
Renner, S. et al.

TABLE 1: Preliminary species list from the Pampa biome in Rio Grande do Sul, Brazil. Municipalities of occurrence and voucher/collection numbers. New records for the state are marked with *.

\begin{tabular}{|c|c|c|c|c|}
\hline Suborder & Family & Species & Municipality & Collection ID \\
\hline \multirow[t]{25}{*}{ Zygoptera } & Calopterygidae & Hetaerina rosea Selys, 1853 & $\mathrm{AL}, \mathrm{MV}, \mathrm{SB}, \mathrm{SF}$ & ZAUMCN1119 \\
\hline & & *Mnesarete lencionii Garrison, 2006 & SF & ZAUMCN1120 \\
\hline & & Mnesarete pudica (Hagen in Selys, 1853) & SF & ZAUMCN1121 \\
\hline & Coenagrionidae & Acanthagrion cuyabae Calvert, 1909 & $\mathrm{AL}$ & ZAUMCN1122 \\
\hline & & Acanthagrion gracile Rambur, 1842 & $\mathrm{AL}, \mathrm{MV}, \mathrm{SB}, \mathrm{SF}$ & ZAUMCN1123 \\
\hline & & Acanthagrion lancea Selys 1876 & $\mathrm{AL}, \mathrm{MV}, \mathrm{SF}$ & ZAUMCN1124 \\
\hline & & Argentagrion ambiguum Ris, 1904 & $\mathrm{AL}, \mathrm{MV}, \mathrm{SF}$ & ZAUMCN1125 \\
\hline & & Argia albistigma (Hagen in Selys, 1865) & $\mathrm{MV}, \mathrm{SB}, \mathrm{SF}$ & ZAUMCN1126 \\
\hline & & *Argia lilacina Selys, 1865 & $\mathrm{AL}, \mathrm{MV}, \mathrm{SF}$ & ZAUMCN1127 \\
\hline & & Argia modesta Selys, 1865 & SF & ZAUMCN1128 \\
\hline & & Argia sp. & SB & ZAUMCN1129 \\
\hline & & Homeoura chelifera Selys, 1876 & $\mathrm{AL}, \mathrm{MV}, \mathrm{SB}, \mathrm{SF}$ & ZAUMCN1130 \\
\hline & & Ischnura capreolus Hagen, 1861 & $\mathrm{AL}, \mathrm{MV}, \mathrm{SB}, \mathrm{SF}$ & ZAUMCN1131 \\
\hline & & Ischnura fluviatilis Selys, 1876 & $\mathrm{AL}, \mathrm{MV}, \mathrm{SB}, \mathrm{SF}$ & ZAUMCN1132 \\
\hline & & *Minagrion waltheri Selys, 1876 & $\mathrm{SF}$ & ZAUMCN1133 \\
\hline & & Neoneura leonardoi Machado, 2005 & $\mathrm{AL}$ & ZAUMCN1134 \\
\hline & & Oxyagrion hempeli Calvert, 1909 & $\mathrm{AL}, \mathrm{MV}, \mathrm{SB}, \mathrm{SF}$ & ZAUMCN1135 \\
\hline & & *oxyagrion rubidum Rambur, 1842 & $\mathrm{SF}$ & ZAUMCN1136 \\
\hline & & Oxyagrion terminale Selys, 1876 & $\mathrm{AL}, \mathrm{MV}, \mathrm{SB}, \mathrm{SF}$ & ZAUMCN1137 \\
\hline & & Telebasis corallina Selys, 1876 & $\mathrm{SB}, \mathrm{SF}$ & ZAUMCN1138 \\
\hline & & Telebasis theodori Navás, 1934 & $\mathrm{MV}, \mathrm{SB}, \mathrm{SF}$ & ZAUMCN1139 \\
\hline & & Telebasis willinki Fraser, 1948 & $\mathrm{AL}, \mathrm{SF}$ & ZAUMCN1140 \\
\hline & & *Gen. nov. sp. nov. (under description) & $\mathrm{AL}$ & ZAUMCN1141 \\
\hline & Heteragrionidae & Heteragrion triangulare (Hagen in Selys, 1862) & SF & ZAUMCN1142 \\
\hline & Lestidae & Lestes bipupillatus Calvert, 1909 & $\mathrm{SB}, \mathrm{SF}$ & ZAUMCN1143 \\
\hline \multirow[t]{31}{*}{ Anisoptera } & Aeshnidae & Castoraeschna sp. & SF & ZAUMCN1144 \\
\hline & & Limnetron debile Karsch, 1891 & SB & ZAUMCN1145 \\
\hline & & Remartinia luteipennis Burmeister 1839 & SF & ZAUMCN1146 \\
\hline & & Rhionaeschna bonariensis Rambur, 1842 & $\mathrm{SB}, \mathrm{SF}$ & ZAUMCN1147 \\
\hline & & Rhionaeschna planaltica Calvert, 1952 & SF & ZAUMCN1148 \\
\hline & & Staurophlebia reticulata Burmeister, 1839 & SF & ZAUMCN1149 \\
\hline & Gomphidae & Aphylla theodorina Navás, 1933 & $\mathrm{SB}, \mathrm{SF}$ & ZAUMCN1150 \\
\hline & & Aphylla molossus Selys, 1869 & MV & ZAUMCN1151 \\
\hline & & *Archaeogomphus densus Belle, 1982 & SB & ZAUMCN1152 \\
\hline & & Progomphus basistictus Ris, 1911 & $\mathrm{MV}, \mathrm{SF}$ & ZAUMCN1154 \\
\hline & & Progomphus sp. & MV & ZAUMCN1153 \\
\hline & Libellulidae & Brachymesia furcata Hagen, 1861 & $\mathrm{SB}, \mathrm{SF}$ & ZAUMCN1155 \\
\hline & & *Brechmorhoga nubecula Rambur, 1842 & SF & ZAUMCN1200 \\
\hline & & *Dasythemis venosa Burmeister, 1839 & SF & ZAUMCN1156 \\
\hline & & Dasythemis mincki mincki Karsh, 1890 & $\mathrm{SB}, \mathrm{SF}$ & ZAUMCN1157 \\
\hline & & Diastatops intensa Montgomery, 1940 & $\mathrm{MV}, \mathrm{SB}, \mathrm{SF}$ & ZAUMCN1158 \\
\hline & & *Diastatops obscura Fabricius, 1775 & $\mathrm{AL}$ & ZAUMCN1159 \\
\hline & & *Dythemis nigra Martin, 1897 & SF & ZAUMCN1160 \\
\hline & & Elasmothemis sp. & SF & ZAUMCN1161 \\
\hline & & Erythemis peruviana Rambur, 1842 & SF & ZAUMCN1162 \\
\hline & & Erythemis plebeja Burmeister, 1839 & SF & ZAUMCN1163 \\
\hline & & *Erythemis vesiculosa Fabricius, 1775 & $\mathrm{AL}, \mathrm{MV}$ & ZAUMCN1164 \\
\hline & & Erythemis sp. & SF & ZAUMCN1165 \\
\hline & & Erythrodiplax atroterminata Ris, 1911 & $\mathrm{AL}, \mathrm{MV}, \mathrm{SB}, \mathrm{SF}$ & ZAUMCN1166 \\
\hline & & Erythrodiplax hyalina Förster, 1907 & $\mathrm{AL}, \mathrm{MV}, \mathrm{SB}, \mathrm{SF}$ & ZAUMCN1167 \\
\hline & & *Erythrodiplax lygaea Ris, 1911 & SF & ZAUMCN1168 \\
\hline & & Erythrodiplax media Borror, 1942 & $\mathrm{AL}, \mathrm{MV}, \mathrm{SB}, \mathrm{SF}$ & ZAUMCN1169 \\
\hline & & Erythrodiplax melanorubra Borror, 1942 & $\mathrm{AL}, \mathrm{MV}, \mathrm{SB}, \mathrm{SF}$ & ZAUMCN1170 \\
\hline & & Erythrodiplax nigricans Rambur, 1842 & $\mathrm{AL}, \mathrm{MV}, \mathrm{SB}, \mathrm{SF}$ & ZAUMCN1171 \\
\hline & & Erythrodiplax paraguayensis Förster, 1905 & $\mathrm{AL}, \mathrm{MV}, \mathrm{SB}, \mathrm{SF}$ & ZAUMCN1172 \\
\hline & & Erythrodiplax sp. & $\mathrm{AL}, \mathrm{MV}, \mathrm{SB}, \mathrm{SF}$ & ZAUMCN1173 \\
\hline
\end{tabular}


TABLE 1: Continued...

\begin{tabular}{|c|c|c|c|c|}
\hline Suborder & Family & Species & Municipality & Collection ID \\
\hline & & *Gynothemis venipunctata Calvert, 1909 & SF & ZAUMCN1174 \\
\hline & & *Idiataphe longipes Hagen, 1861 & $\mathrm{SB}, \mathrm{SF}$ & ZAUMCN1175 \\
\hline & & *Macrothemis heteronycha Calvert, 1909 & $\mathrm{MV}, \mathrm{SB}, \mathrm{SF}$ & ZAUMCN1176 \\
\hline & & Macrothemis imitans Karsch, 1890 & $\mathrm{SB}, \mathrm{SF}$ & ZAUMCN1177 \\
\hline & & *Macrothemis lutea Calvert, 1909 & MV & ZAUMCN1178 \\
\hline & & Macrothemis marmorata Hagen, 1868 & $\mathrm{AL}, \mathrm{MV}, \mathrm{SB}, \mathrm{SF}$ & ZAUMCN1179 \\
\hline & & Miathyria marcella (Selys in Sagra, 1857) & $\mathrm{AL}, \mathrm{MV}, \mathrm{SB}$ & ZAUMCN1180 \\
\hline & & Micrathyria hesperis Ris, 1911 & $\mathrm{AL}, \mathrm{MV}, \mathrm{SF}$ & ZAUMCN1181 \\
\hline & & Micrathyria longifasciata Calvert, 1909 & SF & ZAUMCN1182 \\
\hline & & Micrathyria ocellata Martin, 1897 & $\mathrm{MV}, \mathrm{SB}, \mathrm{SF}$ & ZAUMCN1183 \\
\hline & & *Micrathyria spuria Selys, 1900 & SB & ZAUMCN1184 \\
\hline & & Micrathyria tibialis Kirby, 1897 & $\mathrm{MV}, \mathrm{SF}$ & ZAUMCN1185 \\
\hline & & Micrathyria sp. & SF & ZAUMCN1186 \\
\hline & & Nephepeltia flavifrons Karsch, 1889 & $\mathrm{AL}, \mathrm{MV}, \mathrm{SF}$ & ZAUMCN1187 \\
\hline & & *Orthemis aequilibris Calvert, 1909 & $\mathrm{AL}, \mathrm{MV}, \mathrm{SF}$ & ZAUMCN1188 \\
\hline & & Orthemis ambinigra Calvert, 1909 & $\mathrm{SF}$ & ZAUMCN1189 \\
\hline & & *Orthemis attenuata Erichson, 1848 & $\mathrm{AL}, \mathrm{MV}$ & ZAUMCN1190 \\
\hline & & Orthemis discolor Burmeister, 1839 & $\mathrm{AL}, \mathrm{MV}, \mathrm{SB}, \mathrm{SF}$ & ZAUMCN1191 \\
\hline & & Pantala flavescens Fabricius, 1798 & $\mathrm{AL}, \mathrm{MV}, \mathrm{SB}, \mathrm{SF}$ & ZAUMCN1192 \\
\hline & & Perithemis icteroptera (Selys in Sagra, 1857) & $\mathrm{AL}, \mathrm{MV}$ & ZAUMCN1193 \\
\hline & & Perithemis mooma Kirby, 1889 & $\mathrm{AL}, \mathrm{MV}, \mathrm{SB}, \mathrm{SF}$ & ZAUMCN1194 \\
\hline & & Tauriphila argo Hagen, 1869 & MV & ZAUMCN1195 \\
\hline & & *Tholymis citrina Hagen, 1867 & MV & ZAUMCN1196 \\
\hline & & Tramea abdominalis Rambur, 1842 & MV & ZAUMCN1197 \\
\hline & & Tramea binotata Rambur, 1842 & $\mathrm{AL}, \mathrm{MV}, \mathrm{SB}, \mathrm{SF}$ & ZAUMCN1198 \\
\hline & & Tramea cophysa Hagen, 1867 & $\mathrm{AL}, \mathrm{MV}, \mathrm{SF}$ & ZAUMCN1199 \\
\hline
\end{tabular}

TABLE 2: Number of Odonata species collected per family in Rio Grande do Sul within the Pampa biome.

\begin{tabular}{ccc}
\hline FAMILY & No. & \% \\
\hline Zygoptera & & \\
Calopterygidae & 3 & 3,6 \\
Coenagrionidae & 20 & 24,5 \\
Heteragrionidae & 1 & 1,2 \\
Lestidae & 1 & 1,2 \\
Anisoptera & & \\
Aeshnidae & 6 & 7,3 \\
Gomphidae & 5 & 6,1 \\
Libellulidae & 46 & 56,1 \\
TOTAL & 82 & $100 \%$ \\
\hline
\end{tabular}

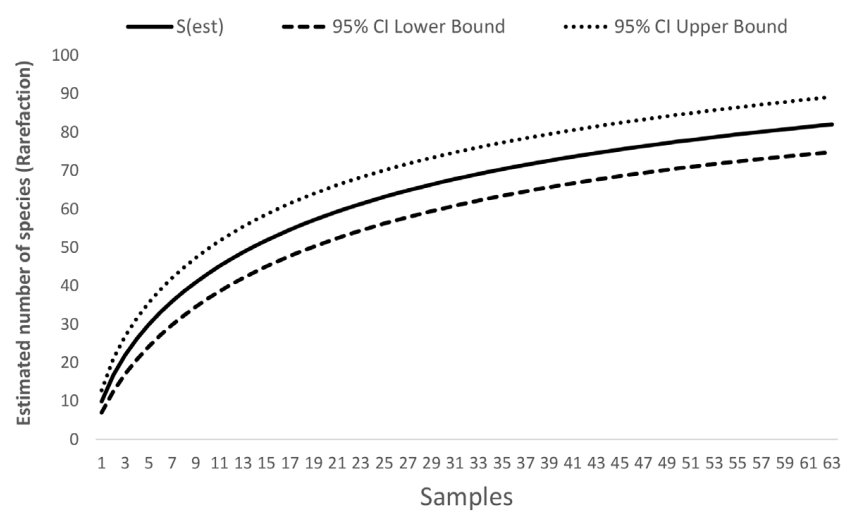

FIGURE 3: Rarefaction curve showing the efficiency of our sampling, stabilization expected to be reached if we continue our efforts. S(est): estimated species number; $95 \% \mathrm{CI}$ : confidence interval, upper and lower.

\section{1 - Mnesarete lencionii Garrison, 2006 (Calopterygidae)}

Rare, at least for the latitude where our survey took place; this species is thought to be distributed all over Southeastern Brazil (Garrison 2006). The species resembles the congeneric M. pruinosa (Hagen in Selys, 1853), differing from it by the presence of a dark pseudopterostigma. Only one male was captured, it was found in a small fast flowing rivulet used for drainage of rice fields. At the same place we also found other calopterygids such as Hetaerina rosea Selys, 1853, which at the time of sampling, was abundant in the area. This species of Mnesarete was recorded from Argentina and Paraguay (Garrison 2006), and from Brazil from MG (Vilela et al. 2016) and SP (Garrison 2006).

\section{2 - Argia lilacina Selys, 1865 (Coenagrionidae)}

An inconspicuous coenagrionid due to its diminutive size (less than $30 \mathrm{~mm}$ ), whose females shows pale brownish to green coloration and males are a bit more colored, varying from grayish blue to black. This species was quite common and we collected more than 80 specimens. It was mostly found in small streams flowing in open/field areas. According to Takiya et al. (2016), this species was previously recorded for Bolivia, Paraguay, and Argentina, and in Brazil for CE, TO, MT, GO, MG, MS, ES, SP and RJ.

\section{3 - Minagrion waltheri Selys, 1876 (Coenagrionidae)}

This Minagrion species was considered a rare species in our dataset, it occurred in small numbers along the margins of lentic waters, such as swamps and marshes (Garrison et al. 2010). It occurs in areas dominated by cattails (Typha), preferring slow moving clear water streams (Santos 1956, 1965). Our specimens occurred at only one sampling site, which had the same environment as that provided by Santos $(1956,1965)$. The clean water seemed to pertain to an underground flow giving it zero or almost zero 
turbidity. The previously known records for this species are from MG (Bedê et al. 2015) and SP (Selys 1876; Santos 1965). We thus expand its distribution more than $1,200 \mathrm{~km}$ southwards. The species may well occur in between these two regions, but there are no records, probably due to lack of sampling.

\section{4 - Oxyagrion rubidum (Rambur, 1842) (Coenagrionidae)}

This species was locally common, alongside with $O$. terminale Selys, 1876 , and difficult to identify in the field due to the resemblance of the two species. The environment where it was found was characterized by dense marginal vegetation on rivers, streams and ponds. This species is known from Uruguay (von Ellenrieder et al. 2009), Paraguay (Heckman 2010), Argentina and Chile (Muzón et al. 2014). From Brazil there is only one record in SP (Costa et al. 2000).

\section{5 - Archaeogomphus densus Belle, 1982 (Gomphidae)}

This is a small gomphid, pale colored which makes it inconspicuous in the forest and fields. It is known by its agile and rapid flight that makes it difficult to collect (Belle 1982). This genus is easily identified by its unique characters: two latero-dorsal hooks on the male S10 (Garrison et al. 2006). We consider this species as poorly known since the only records found are the original description from Argentina and MG by Belle (1982). Our unique specimen (male) was caught in a rocky fast flowing stream with sandy margins and covered by low vegetation.

\section{6 - Brechmorhoga nubecula Rambur, 1842 (Libellulidae)}

This species was considered rare to our sampling efforts, since it was found on only one occasion in a fast flowing stream, with a shaded marginal zone. It could be easily confused with some species belonging to the Macrothemis genus. According to Kompier (2015) it can be overlooked due to its secretive habitats, which was proven true by our sampling experience. According to Heckman (2006) this species occurs in almost all southern American countries, and in Brazil there are records from CE (Takyia et al. 2016), RJ (Assis et al. 2004, Kompier 2015), MG (Souza et al. 2013, Bedê et al. 2015) and SP (Costa et al. 2000).

\section{7 - Dasythemis venosa Burmeister, 1839 (Libellulidae)}

This forest species was found only in well preserved environments, such as small forest fragments, in shaded areas or natural clearings (at fallen trees), perching on dry twigs above the water. Records of this species are from Argentina and Paraguay (Heckman 2006) and from Brazil there are records from SP (Costa et al. 2000) and MG (Souza et al. 2013).

\section{8 - Diastatops obscura (Fabricius, 1775) (Libellulidae)}

A conspicuous species that has dark colored wings and butterfly-like flying style. Our specimens were found in rich marginal vegetation of streams and lakes. The species can be easily confused with its congener Diastatops intensa Montgomery, 1940, which also occurred at the same localities. This species is known from many countries in South America, including Paraguay and Argentina (Heckman 2006); from Brazil there are records from, MG (Bedê et al. 2015, Vilela et al. 2016), MS (Dalzochio et al. 2011), MT (Calvão et al. 2014), RJ (Kompier 2015) and SP (Costa et al. 2000). The species probably occurs in all Brazilian states, but was not previously detected in RS due to lack of sampling.

\section{9 - Dythemis nigra Martin, 1897 (Libellulidae)}

At our sampling sites this species seemed to be rare, found on only one location, a small slow-flowing clear water stream. Our specimen was caught perching on twigs in a shaded marginal zone close to the water. The distribution records for this species, according to Takiya et al. (2016), are from Mexico, Panama, Trinindad and Tobago, Colombia, Venezuela, Guyana, Suriname, French Guiana, Ecuador, Peru, Paraguay, Argentina and Brazil: AM, BA, CE, ES, GO, MG, MS, MT, PA, PE, RJ, SC and SP.

\subsection{0 - Erythemis vesiculosa Fabricius, 1775 (Libellulidae)}

A very conspicuous species, characterized by its flying habits when it is hovering at low height above the water surface. Numerous specimens were observed, mostly at the lakes, and male-to-male territorial disputes and fight behavior was observed on several occasions. This species also has a wide distribution since there are records from many countries in South America. In Brazil the records are from several states: MG (Bedê et al. 2015), MS (Dalzochio et al. 2011), MT (Calvão et al. 2014), RJ (Assis et al. 2004, Kompier 2015) and SP (Costa et al. 2000).

\subsection{1 - Erythrodiplax lygaea Ris, 1911 (Libellulidae)}

This is a tiny libellulid species whose males have bright yellowish colors that make the identification easy in the field. In our survey it occurred only on two locations, which were slow flowing water areas fed by small streams, corroborating the information provided by Costa et al. (2001) describing the larvae of the species. It is known to occur in Brazil (Pirassununga, SP), Paraguay and Argentina (Jurzitza 1981, Costa et al. 2001, Garrison et al. 2006).

\subsection{2 - Gynothemis venipunctata Calvert, 1909 (Libellulidae)}

A species which is easily identifiable in the field by the yellowish or amber spots on the male wing bases. Our six specimens were caught flying in a similar motion to that of Macrothemis, at about $1.5 \mathrm{~m}$ height, above open field areas, corroborating the observations made by Garrison (1983). Also, some were seen at a distance, flying in swarm-like formations consisting of some 5 to 10 specimens close to tree tops of about $10 \mathrm{~m}$ height. The species is known from Venezuela (De Marmels 1983) and in Brazil from MS (Costa et al. 1998), RJ (Kompier 2015) and SP (Costa et al. 2000).

\subsection{3 - Idiataphe longipes Hagen, 1861 (Libellulidae)}

We considered this species as common only in the peak of the summer season (Dec - Feb), since it was found in large numbers, usually perching on dry twigs along the water's edge. It seems to prefer lakes with diverse marginal or aquatic vegetation. There are records from several countries of South America: Colombia, Peru, Venezuela, Paraguay and Guyana. From Brazil the records are from the following states: SP (Costa et al. 2000), RJ (Kompier 2015), ES (Heckman 2006) and MG (Bedê et al. 2015).

\subsection{4 - Macrothemis heteronycha Calvert in Ris, 1909 (Libellulidae)}

Most of our 14 specimens were caught at temporary waters or small creeks with sandy and rocky bottom. Its flight behavior resembles in some ways that of Gynothemis venipunctata; a slow and fragile style, very different form the great majority of dragonflies. Also, opposite to most of its congeners, $M$. heteronycha was found mostly in open areas instead of forest with closed canopy. According to the literature, it occurs in Paraguay, Argentina (Ris 1913, Garrison \& von Ellenrieder 2006) and Brazil: SP, RJ, MG, MS, ES and SC (Costa et al. 2000, Dalzochio et al. 2011).

\subsection{5 - Macrothemis lutea Calvert, 1909 (Libellulidae)}

A very interesting and unexpected finding. Our specimens were caught in tandem along a flooding area near to a river sand bank (Figure 2b). At first sight they were thought to be gomphids, due to the long abdomen (big overall size for a Macrothemis species) and general appearance. It is a rare species described from Brazil, known to occur in the state of SE which 
is the species type locality (Calvert 1909) and recently registered in CE (Nobre \& Carvalho 2014). Here the distribution of the species is expanded southwards about 4,000 km.

\subsection{6 - Micrathyria spuria Selys, 1900 (Libellulidae)}

A common species, easily identified by the abdominal markings and the dorsally whitish cerci. We found this species mostly in lakes and swamps with abundant marginal vegetation. It showed the typical Micrathyria behavior of perching on tips of emergent vegetation or dry twigs. The females we caught were found away from the water bodies, perching and foraging around trees and bushes. The species is known to occur in Venezuela (De Marmels 1983), Paraguay and Argentina (von Ellenrieder 2009) and Brazil: MG, MS, PR, RJ and SP (Costa et al. 2000, 2002).

\subsection{7 - Orthemis aequilibris Calvert, 1909 (Libellulidae)}

Most of our specimens were found in the same localities as $M$. heteronycha; temporary waters or small perennial rocky creeks. Some of them were found away from the water. This species has records from Panama, Colombia, Peru, Venezuela, French Guiana, Guyana, Surinam, Bolivia, Paraguay, and from Brazil it has been recorded in BA, ES, MG and RJ (Costa et al. 2000) and AM, CE, MS, PA and PI (Takiya et al. 2016).

\subsection{8 - Orthemis attenuata Erichson, 1848 (Libellulidae)}

The males resemble a bit the darker species of the genus Erythemis, while the females have a typical and unique color scheme: dark brown with yellowish stripes. Most of our specimens were caught in a temporary river flood pool, which was muddy at the time of our sampling efforts, in the spring season. Strong male-to-female harassment was observed, as well as male-to-male territorial disputes. There are records from several countries in South America (von Ellenrieder 2012); in Brazil it is known to occur in PA (Pinto \& Carvalho 2009), RJ (Kompier 2015), BA, ES and MT (von Ellenrieder 2012).

\subsection{9 - Tholymis citrina Hagen, 1867 (Libellulidae)}

This species is known by its crepuscular habits and erratic flight, usually found over marshes hunting mosquitoes (Paulson 2001). Our specimens were caught during the first minutes of our sampling efforts early in the morning (09:00 am), flying at irregular intervals in shaded areas which made them difficult to see and to capture with insect nets. This species was only found in the flooded areas, near to the Ibicuí River. In Brazil the records are known from the following states: MS (Costa et al. 1998), MT (Juen et al. 2014), RJ (Costa et al. 2002) and SP (Costa et al. 2000).

\section{Discussion}

Conservation strategies depend basically from information about diversity distribution, biogeography, population and community ecology. Therefore, inventories play a key role for the development of such measures. In this survey, we increased the knowledge on the Odonata fauna of Brazil's Pampa biome. We found 82 species, reflecting the diversity of our sampling sites; including several types of aquatic systems, most of them located in man-influenced areas, mostly by agriculture. Of these species, no less than 19 were new to the state and one new species not described in this paper. Naturally the number of species in the area will increase by including more sample sites and resampling ours, but never-the-less we already can see a highly diverse fauna in the region. We registered a large number (46) of Libellulidae species, which could be the result of many widespread generalists occurring in the mosaic of open fields and agriculture areas with little riparian fragmented forest, a landscape which is known to favor the fast and agile flying dragonflies, supporting the findings of Machado
(2001). As suggested by Corbet (1999), there are different responses from Anisoptera and Zygoptera to environmental conditions, since the latter are known as low range dispersers (Vieira \& Cordero-Rivera 2015). In general, there are clear relations between environmental factors (biotic and abiotic) and species composition, these factors acting as determinants of presence and absence of some species due to ecological and physical restrictions (e.g., Paulson 2006, Juen et al. 2007). This is naturally an oversimplified division as Zygoptera is a taxonomical and not an ecological unit and contains both good (Flenner \& Sahlén 2008) as well as weak (Lorenzo-Carballa et al. 2015) dispersers, but as an average assumption it is valid also when analysing large scale species patterns (Heiser \& Schmitt 2013). We found many rare species in the study (singletons $n=20$ ), all having a restricted occurrence. We consider the following possible explanations: first, we found a high number of species of Coenagrionidae (20), some of which can mirror good ecological conditions even in a highly fragmented region, acting then as bioindicators (Clausnitzer 2003, Suhling et al. 2006, Samways \& Sharrat 2010, Renner et al. 2016a). Following this idea, in the open grassland with longer dispersal distances in the open, more exposed surroundings between suitable habitats (Juen et al. 2007), fewer of the smaller bodied species have the possibility to occur. This is due to some genera having ecological restrictions related to aquatic vegetation (i.e. plant diversity) and water quality (e.g., Argia, Homeoura, Oxyagrion) as stated by Garrison et al. (2010). Second, in well preserved areas or large forested areas, higher number of Zygopterans such as Heteragrionidae, Calopterygidae and again coenagrionids are expected to be found, many of which have specific environmental restrictions and ecological needs, mostly regarding to diversity of plants and vegetal structures in the riparian areas (Juen et al. 2014, Carvalho et al. 2013). This fact can explain the occurrence of Minagrion waltheri (Coenagrionidae) in only one locality in SA, which is a well-preserved area that keeps its natural features, as well crystal clear water and high diversity of aquatic/riparian vegetation (Figure 2a). These specialized species can function as powerful tools when distinguishing priority areas for preservation, as many of such restricted species have been proposed to be good indicators of environmental quality (Clausnitzer 2003, Sahlén 2006, Koch et al. 2014).

When compared to other studies from the Neotropics (De Marco et al. 2014, Monteiro et al. 2013) our collection efficiency captured only $81 \%$ of the expected diversity, tending to reach its asymptote, implying that the actual number of species in the region could be as high as 101 (cf., Figure 3). We have a relatively low number of sampling sites and, hence, cannot see the full picture of the odonate diversity in the Pampa biome, given its dimensions. However, we tried to include every kind of aquatic environment which could shelter any species of Odonata, from small puddles of temporary water to big rivers, lakes and perennial bogs; more than one of each. To our surprise, we found several interesting habitats in which we recorded most of the species that we considered rare. These habitats could be starting point for future conservation actions to be taken for diversity maintenance in the area. Special focus should therefore be given to the environments whose original features are still preserved, such as small rivulets flowing in ravines, swampy and well vegetated areas supplied by underground waters and forest remnants with waterbodies (Figures 2a, b, c).

Future studies should, if possible, include a bigger selection of environments from more municipalities to obtain a more complete sample of the communities. In addition, more frequent sampling during the seasons might also contribute to the inventory, given that some species are related to specific conditions to be active, e.g. crepuscular flight, which occur among many Aeshnidae that are active only in the twilight. There are also species that are active during rainy conditions (Garrison 1989, Wasscher 1990, Corbet 1999), some of which might occur in the Pampa region.

The knowledge achieved in other biomes of Brazil is much deeper than that from the Pampa. But this biome is considered a highly biodiverse 
system (Overbeck et al. 2009), and in this context, species surveys can supply valuable initial information for the actions needed to preserve and restore these environments. With this survey we tried to add further information and improve the knowledge of the group Odonata from the Pampa biome of southern Brazil, showing that even under such fragmented and altered conditions diversity is still high; this fact acknowledges that future measurements of conservation and restoration are needed.

\section{Acknowledgements}

We are thankful to Capes (Coordenação de Aperfeiçoamento de Pessoal de Nível Superior) for a doctoral fellowship to SR and a PVE cooperation program between UNIVATES and Halmstad University (88881.068147/2014-01); UNIVATES for logistical and funding support; IBAMA for the collection permit; Mrs. Úrsula Arend (MCNU), for the labeling of our collection; Mr. Daniel Martins dos Santos for the image processing; and to the landowners who kindly agreed with the development of our study on their properties.

\section{Author's contribution}

Samuel Renner: Contribution to data collection, contribution to data analysis and interpretation, contribution to manuscript preparation and contribution to critical revision, adding intellectual content.

Eduardo Périco: Contribution to data analysis and interpretation, contribution to manuscript preparation and contribution to critical revision, adding intellectual content.

Gerson Júnior Ely: Contribution to data collection.

Göran Sahlén: Contribution to data collection, contribution to data analysis and interpretation, contribution to manuscript preparation and contribution to critical revision, adding intellectual content.

\section{Conflicts of interest}

The authors declare that they have no conflict of interest related to the publication of the manuscript.

\section{References}

ANJOS-SANTOS, D. \& COSTA, J.M. 2006. A revised checklist of Odonata (Insecta) from Marabaia, Rio de Janeiro, Brazil with eight new records. Zootaxa 1300:37-50.

ASSIS, J.C.F., CARVALHO, A.L. \& NESSIMIAN, J.L. 2004. Composição e preferência por microhábitat de imaturos de Odonata (Insecta) em um trecho de baixada do Rio Ubatiba, Maricá, RJ, Brasil. Rev. Bras. Entomol. 48(2):273282. http://dx.doi.org/10.1590/S0085-56262004000200017

BEDÊ, L.C., MACHADO, A.B.M., PIPER, W. \& SOUZA, M.M. 2015. Odonata of the Serra de São José - Brazil's first Wildlife Reserve aimed at the conservation of dragonflies. Notulae Odonatologicae 8(5):117-155.

BEHLING, H., PILLAR, V.P., ORLÓCI, L. \& BAUERMANN, S.G. 2004. Late Quaternary Araucaria forest, grassland (campos), fire and climate dynamics, studied by high-resolution pollen, charcoal and multivariate analysis of the Cambará do Sul core in southern Brazil. Palaeogeography, Palaeoclimatology, Palaeoecology 203:277-297. http://dx.doi.org/10.1016/S0031- 0182(03)00687-4

BELLE, J. 1982. A review of the genus Archaeogomphus Williamson (Odonata, Gomphidae). Tijdschrift voor Entomologie 125(3):37-56.

BENCKE, G.A. 2009. Diversidade e conservação da fauna dos campos do sul do Brasil. In Campos Sulinos - conservação e uso sustentável da biodiversidade (Pillar, V.P., Müller, S.C., Castilhos, Z.M.S. \& Jaques, A.V.A., eds), Ministério do Meio Ambiente, Brasília, Brazil.

CALVÃO, L.B., DE MARCO JÚNIOR, P. \& BATISTA, J.D. 2014. Odonata (Insecta) from Nova Xavantina, Mato Grosso, Central Brazil: Information on species distribution and new records. Check List 10:299-307. http://dx.doi. org $/ 10.15560 / 8670$
CALVERT, P.P. 1909. Contributions to a knowledge of the Odonata of the Neotropical region, exclusive of Mexico and Central America. Annals of the Carnegie Museum 6:73-280.

CARDOSO, P., ERWIN, T.L., BORGES, P.A.V. \& NEW, T.R. 2011. The seven impediments in invertebrate conservation and how to overcome them. Biol. Conserv. 144:2647-2655. http://dx.doi.org/10.1016/j.biocon.2011.07.024

CARVALHO, F.G., PINTO, N.S., OLIVEIRA, J.M.B. \& JUEN, L. 2013. Effects of marginal vegetation removal on Odonata communities. Acta Limnologica Brasiliensia 25:10-18. http://dx.doi.org/10.1590/S2179-975X2013005000013

CLAUSNITZER, V. 2003. Dragonfly communities in coastal habitats of Kenya: indication of biotope quality and the need of conservation measures. Biodiv. Conserv. 12:333-356. http://dx.doi.org/10.1023/A:1021920402913

CORBET, P.S., 1999. Dragonflies: Behavior and Ecology of Odonata. Cornell University Press, Ithaca, NY, $829 \mathrm{p}$.

COSTA, J.M., SOUZA, L.O.I \& SANTOS, T.C. 1998. Uma lista preliminar dos Odonatos do Pantanal Sul Mato-grossense com a descrição da fêmea de Acanthagrion chararum Calvert, 1909, Parte I (unpublished data).

COSTA, J.M., A.B.M. MACHADO, F.A.A. LENCIONI \& T.C. SANTOS. 2000 Diversidade e distribuição dos Odonata (Insecta) no Estado de São Paulo, Brasil: Parte I - Lista das espécies e registros bibliográficos. Publ. Av. Mus. Nac. 80:1-27. http://www.angelfire.com/mn/janira/trabalhos/pa80.pdf

COSTA, J.M., VIEIRA, L.P. \& LOURENÇO, A.N. 2001. Descrição de três larvas de Erythrodiplax Brauer, 1868, e redescrição das larvas de E. pallida (Needham, 1904) e E. umbrata (Linnaeus, 1758) com chave para identificação das larvas conhecidas das espécies brasileiras (Odonata: Libellulidae). Bol. Mus. Nac. RJ, Zoologia, Nova Série 4665:1-16.

COSTA, J.M., LOURENÇO, A.N. \& VIEIRA, L.P. 2002. Micrathyria pseudhypodidyma sp. n. (Odonata: Libellulidae) com chave das espécies do gênero que ocorrem no estado do Rio de Janeiro. Neotrop. Entomol. 31(3):377-389.

COSTA, J.M. \& B.B. OLDRINI. 2005. Diversidade e distribuição dos Odonata (Insecta) no Estado do Espírito Santo, Brasil. Publ. Av. Mus. Nac. 107:1-15. http://dx.doi.org/10.1590/S0085-56262011000100014

DALZOCHIO, M.S., SOUZA, L.O.I., UCHOA, M.A. \& COSTA, J.M. 2011. First records of Odonata (insecta) from the Bodoquena Mountains, Mato Grosso do Sul, Brazil. EntomoBrasilis 4(3): 135-138.

DE MARCO, P. \& VIANNA, D.M. 2005. Distribuição do esforço de coleta de Odonata no Brasil - subsídios para a escolha de áreas prioritárias para levantamentos faunísticos. Lundiana 6:13-26.

DE MARCO, P., NOGUEIRA, D.S., CORREA, C., VIEIRA, T.B., SILVA, K.D., PINTO, N.S., BICHSEL, D., HIROTA, A.S.V., VIEIRA, R.R.S., CARNEIRO, F.M., OLIVEIRA, A.A.B., CARVALHO, P., BASTOS, R.P., ILG, C. \& OERTLI, B. 2014. Patterns in the organization of Cerrado pond biodiversity in Brazilian pasture landscapes. Hydrobiologia 723:87-101. http://dx.doi.org/10.1007/ s10750-013-1695-2

DE MARMELS, J. 1983. Hallazgo de odonata nuevos para Venezuela o poco conocidos. 3. Boletín de Entomología Venezolana Nova Serie 2(19):155-156.

DIJKSTRA, K.-D.B., BECHLY, G., BYBEE, S.M., DOW, R.A., DUMONT, H.J., FLECK, G., GARRISON, R.W., HÄMALÄINEN, M., KALKMAN, V.J., KARUBE, H., MAY, M.L., ORR, A.G., PAULSON, D.R., REHN, A.C., THEISCHINGER, G., TRUEMAN, J.W.H., VAN TOL, J., VON ELLENRIEDER, N. \& WARE, J. 2013. The classification and diversity of dragonflies and damselflies (Odonata). In Animal biodiversity: an outline of higher-level classification and survey of taxonomic richness (Zhang Z.-Q. eds.), Zootaxa 3703:1-82

DIJKSTRA, K.B., KALKMAN, V.J., DOW, R.A., STOKVIS, F.R. \& VAN TOL, J. 2014. Redefining the damselfly families: a comprehensive molecular phylogeny of Zygoptera. Syst. Entomol. 39:68-96. http://dx.doi.org/10.1111/syen.12035

DINIZ-FILHO, J.A.F., DE-MARCO, P. \& HAWKINS, B.A. 2010. Defying the curse of ignorance: perspectives in insect macroecology and conservation biogeography. Insect Conserv. Diver. 3:172-179. http://dx.doi.org/ 10.1111/j.17524598.2010.00091.x

FERREIRA-PERUQUETTI, P.S. \& FONSECA-GESSNER, A.A. 2003. Comunidade de Odonata (Insecta) em áreas naturais de Cerrado e monocultura no nordeste do Estado de São Paulo, Brasil: relação entre o uso do solo e a riqueza faunística. Rev. Bras. Zool. 20(2):219-224. 
FLENNER, I. \& SAHLEN, G. 2008. Dragonfly community re-organisation in boreal forest lakes: rapid species turnover driven by climate change? Insect Conserv. Div. 1:169-179. http://dx.doi.org/j.1752-4598.2008.00020.x

GARRISON, R.W. 1983. Odonata collected in Canaima, Venezuela, in September 1980. Notulae Odonatologicae 2(2):24-25.

GARRISON, R.W. 1989. Brazil, Rondonia State. Argia, Supplement: 2-4.

GARRISON, R.W., 2006. A synopsis of the genera Mnesarete Cowley, Bryoplathanon gen. nov., and Ormenophlebia gen. nov. (Odonata: Calopterygidae). Contributions to Science, Natural History Museum of Los Angeles County, 506:1-84.

GARRISON, R.W. \& VON ELLENRIEDER, N. 2006. Generic diagnoses within a confusing group of genera: Brechmorhoga, Gynothemis, Macrothemis, and Scapanea (Odonata: Libellulidae). Canadian Entomologist 138:269-284. https:// doi.org/10.4039/n05-048

GARRISON, R.W., VON ELLENRIEDER, N. \& LOUTON, J.A. 2006. Dragonfly genera of the new world: an illustrated and annotated key to the Anisoptera. The John Hopkins University Press, Baltimore, USA, 368 p.

GARRISON, R.W., VON ELLENRIEDER, N. \& LOUTON, J.A. 2010. Damselfly genera of the new world: an illustrated and annotated key to the Zygoptera. The John Hopkins University Press Baltimore, USA, 490 p.

GOTELLI, N.J., \& COLWELL, R.K. 2011. Estimating species richness. In Magurran A and McGill B (eds.) Biological Diversity: Frontiers in Measurement and Assessment, pp. 39-54. Oxford University Press, Oxford, USA.

HECKMAN, C.W. 2006. Encyclopedia of South American aquatic insects: Odonata - Anisoptera. Springer, Dordrecht, The Netherlands, 725 p.

HECKMAN, C.W. 2008. Encyclopedia of South American aquatic insects: Odonata - Zygoptera. Springer Washington DC, USA, 691 p.

HEISER, M. \& SCHMITT, T. 2013. Tracking the boundary between the Palaearctic and the Oriental region: new insights from dragonflies and damselflies (Odonata). J. Biogeography 40:2047-2058. http://dx.doi.org /jbi.12133

IBGE - Instituto Brasileiro de Geografia e Estatística. 2016. Mapas dos Biomas do Brasil. Accessed at http://www.ibge.gov.br, 14 April 2016.

INPE - Instituto Nacional de Pesquisas Espaciais. 2014. Centro de Previsão de Tempo e Estudos Climáticos, Banco de Dados Meteorológicos. Ministério da Ciência e Tecnologia. World Wide Web publication. http://bancodedados.cptec. inpe.br/. Assessed on March 2017.

JETZ, W., MCPHERSON, J.M. \& GURALNICK, R.P. 2012. Integrating biodiversity distribution knowledge: toward a global map of life. Trends in Ecology and Evolution 27:151-159. http://dx.doi.org/10.1016/j.tree.2011.09.007

JUEN, L., CABETTE, H.S.R. \& DE MARCO, P. 2007. Odonate assemblage structure in relation to basin and aquatic habitat structure in Pantanal wetlands. Hydrobiologia 579:125-134. http://dx.doi.org/10.1007/s10750-006-0395-6

JUEN, L., OLIVEIRA-JÚNIOR, J.M.B., SHIMANO, Y., MENDES, T.P. \& CABETTE, H.S.R. 2014. Composição e riqueza de Odonata (Insecta) em riachos com diferentes níveis de conservação em um ecótone Cerrado-Floresta Amazônica. Acta Amazonica 44(2):175-184.

JURZITZA, G. 1981. Lista provincional de los odonates de Parque Nacional Iguazú, Província de Misiones, República Argentina. Notulae Odonatologicae 1(7):117-118

KERR, J.T., SUGAR, A. \& PACKER, P. 2000. Indicator taxa, rapid biodiversity assessment and nestedness in an endangered ecosystem. Conserv. Biol. 14:17261734. http://dx.doi.org/10.1111/j.1523-1739.2000.99275.x

KITTEL, R.N. \& ENGELS, W. 2014. Diversity of damselflies (Odonata: Zygoptera) of the state of Rio Grande do Sul, Brazil, with four new records for the state. Notulae Odonatologicae 8(3): 49-55.

KOCH K., WAGNER, C. \& SAHLÉN, G., 2014. Farmland versus forest: comparing changes in Odonata species composition in western and eastern Sweden. Insect Conserv. Div. 7:22-31. http://dx.doi.org/10.1111/icad.12034

KOMPIER, T. 2015. A guide to the Dragonflies and Damselflies of the Serra dos Orgaos, South-eastern Brazil. REGUA Publications, Belgium, 379 p.

LENCIONI, F.A.A. 2006. The Damselflies of Brazil: An Illustrated Identification Guide 2 - Coenagrionidae. All Print Editora, São Paulo, Brazil, 419 p.

LEWIS, O.T. 2006. Climate changes, species-area curves and the extinction crisis. Philosophical Transactions of the Royal Society 361:163-171. http://dx.doi. org/10.1098/rstb.2005.1712
LORENZO-CARBALLA, M.O., FERREIRA, S., SIMS, A.M., THOMPSON, D.J., WATTS, P.J., CHER, Y., DAMOY, V., EVRARD, A., GELEZ, W. \& VANAPPELGHEM, C. 2015. Impact of landscape on spatial genetic structure and diversity of Coenagrion mercuriale (Zygoptera: Coenagrionidae) in northern France. Freshw. Sci. 34:1065-1078. http://dx.doi.org/10.1086/682687

MACHADO, A.B.M. 2001. Studies on neotropical Protoneuridae (Odonata, Zygoptera). Rev. Bras. Zool. 21:333-336. http://dx.doi.org/10.1098/rstb.2005.1712

MMA - Ministério do Meio Ambiente. 2002. Biodiversidade Brasileira: Avaliação e identificação de áreas e ações prioritárias para conservação, utilização sustentável e repartição dos benefícios da biodiversidade nos biomas brasileiros. Ministério do Meio Ambiente, Brasília. World Wide Web publication. http://www.camara. gov.br/internet/comissao/index/perm/capr/ mapa.pdf. Accessed on April 2017.

MMA - Ministério do Meio Ambiente. 2009. Maps of plant distribution in the Brazilian biomes. World Wide Web publication. http://www.mma.gov.br/ estruturas/sbf chm rbbio/ arquivos/mapas cobertura vegetal.pdf. Accessed on April 2017.

MONTEIRO, C.S., COUCEIRO, S.R.M., HAMADA, N. \& JUEN, L. 2013. Effect of vegetation removal for road building on richness and composition of Odonata communities in Amazonia, Brazil. Intl. J. Odonatology 16:135-144. http:// dx.doi.org/10.1080/13887890.2013.764798

MUZÓN, J., PESSACQ, P. \& LOZANO, F. 2014. The Odonata (Insecta) from Patagonia: a synopsis of their current status with illustrated keys for their identification. Zootaxa 3784(4):346-388. http://dx.doi.org/10.11646/zootaxa.3784.4.2

NOBRE, C.E. \& CARVALHO, A.L. 2014. Odonata of Itatira, a Brazilian semi-arid area in the state of Ceará. Intl. J. Odonatology 17(2-3):73-80. http://dx.doi.org /10.1080/13887890.2014.907545

OLIVEIRA, U., SOARES-FILHO, B.S., PAGLIA, A.P., BRESCOVIT, A.D., CARVALHO, C.J.B, SILVA, D.P., REZENDE, D.T., LEITE, S.F.S., BATISTA, J.A.N., BARBOSA, J.P.P.P., STEHMAN, J.R., ASCHER, J.S., VASCONCELOS, M.S., DE MARCO, P., LÖWENBERG-NETO, P., FERRO, V.G. \& SANTOS, A.J. 2017. Biodiversity conservation gaps in the Brazilian protected areas. Scientific reports 7:9141. http://dx.doi.org/10.1038/s41598-017-08707-2

OVERBECK, G.E., MÜLLER, S.C., FIELIS, A., PFHADENAUER, J., PILLA, V.P., BLANCO, C.C., BOLDRINI, I.I., BOTH, R. AND FORNECK, E.D. 2009. Os Campos Sulinos: um bioma negligenciado. In Campos Sulinos - conservação e uso sustentável da biodiversidade. (Pillar, V.P., Müller, S.C., Castilhos, Z.M.S. \& Jacques, A.V.A. eds.) Ministério do Meio Ambiente, Brasília, Brazil, p.24-41.

PAULSON, D.R. 2001. Recent Odonata records from southern Florida - effects of global warming? Intl. J. Odonatology 4(1):57-69.

PAULSON, D. 2006. The importance of forests to neotropical dragonflies. In Forest and Dragonflies - 4th WDA International Symposium of Odonatology (Cordero Rivera, A. eds.). Pensoft Publishers, Sofia, Bulgaria, p.79-101.

PINTO, A.P. \& CARVALHO, A.L. 2009. On a Small Collection of Dragonflies from Barcarena Municipality, Pará State, Brazil, with the Rediscovery of Acanthallagma luteum Williamson \& Williamson. Bulletin of American Odonatology 11(1):11-16.

RENNER, S., PÉRICO, E., SAHLÉN, G., SANTOS, D.M. \& CONSATTI, G. 2015. Dragonflies (Odonata) from the Taquari River valley region, Rio Grande do Sul, Brazil. Check List 11(5):1740. http://dx.doi.org/10.15560/11.5.1740

RENNER, S., PÉRICO, E. \& SAHLÉN, G. 2016a. Testing Dragonflies as Species Richness Indicators in a Fragmented Subtropical Atlantic Forest Environment. Neotrop. Entomol. 45:231-239. http://dx.doi.org/10.1007/s13744-015-0355-9

RENNER, S., PÉRICO, E. \& SAHLÉN, G. 2016b. List of Odonates from the Floresta Nacional de São Francisco de Paula (FLONA - SFP), with two new distribution records for Rio Grande do Sul, Brazil. Biota Neotropica 16(3):e20150132. http://dx.doi.org/10.1590/1676-0611-BN-2015-0132

RIS, F. 1913. Libellulinen 7. Collections Zoologiques du Baron Edmond de SelysLongchamps. Catalogue Sistématique et Descriptif, Bruxelas pp. 837-964.

ROESCH, L.F.W., VIEIRA, F.C.B., PEREIRA, V.A., SCHÜNEMANN, A.L., TEIXEIRA, I.F., SENNA, A.J.T. \& STEFENON, V.M. 2009. The Brazilian Pampa: a fragile biome. Diversity 2009(1):182-198.

ROIG, S.J. \& FLORES, G.E. 2001. Historia biogeográfica de las áreas áridas de América del Sur Austral. In Introducción a la biogeografía en Latinoamérica: Teorías, conceptos, métodos y aplicaciones. (Llorente Bousquets, J. \& Morrone, J.J. eds.). Facultad de Ciencias UNAM, México, p. 257-266. 
SAHLÉN, G. (2006). Specialists vs. generalists among dragonflies - the importance of forest environments to form diverse species pools; pp. 153-179, in: CorderoRivera, A. (eds.) Forests and dragonflies. Moscow and Sofia: Pensoft publishers.

SAMWAYS, M.J. \& SHARRATT, N.J. 2010. Recovery of endemic dragonflies after removal of invasive alien trees. Conserv. Biol. 24:267-277. http://dx.doi. org/j.1523-1739.2009.01427.x

SANTOS, N.D. 1956. Telagrion serracipoensis sp. n. (Coenagriidae, Odonata). Rev. Brasil. Biol. 16(3):369-374.

SANTOS, N.D. 1965. Contribuição ao conhecimento dos "Odonata" da região de Poços de Caldas, MG. "Minagrion" gen. n., para "Telagrion mecistogastrum" Selys Longchamps 1865, com a descrição de uma nova espécie. Atas Soc. Biol. RJ 9(1):8-12.

SELYS-LONGCHAMPS, E. 1876. Synopsis des Agrionines, 5me legion: Agrion (suite). Le genre Agrion. Bulletin de l'Académie royale de Belgique 2(4):247-322.

SMITH, E. \& VAN BELLE, G. 1984. Non parametric estimation of species richness. Biometrics 40: 119-129.

SOUZA, M.M., SOUZA, B., PEREIRA, M.C.S. \& MACHADO, A.B.M. 2013. List of Odonates from Mata do Baú, Barroso, Minas Gerais, Brazil. Check List 9(6):1367-1370. http://dx.doi.org/10.15560/9.6.1367

SUHLING, F., SAHLÉN G., MARTENS, A., MARAIS, E. \& SCHÜTTE, C. 2006. Dragonfly assemblage composition and diversity in arid tropical environments: a case study from western Namibia. Biodiv. Conserv. 15:311-332. http://dx.doi. org/10.1007/s10531-005-2007-6)

TAKIYA, D.M., SANTOS, A.P.M., PINTO, A.P., HENRIQUES-OLIVEIRA, A.L., CARVALHO, A.L., SAMPAIO, B.H.L., CLARLSON, B., MOREIRA, F.F.F., AVELINO-CAPISTRANO, F., GONÇALVES, I.C., CORDEIRO, I.R.S., CÂMARA, J.T., BARBOSA, J.F., SOUZA, R.M. \& RAFAEL, J.A. 2016. Aquatic Insects from the Caatinga: checklists and diversity assessments of Ubajara (Ceará State) and Sete Cidades (Piauí State) National Parks, Northeastern Brazil. Biodiv. Data J. 4: e8354. http://dx.doi.org/10.3897/BDJ.4.e8354
TROAST, D., SUHLING, F., JINGUJI, H., SAHLÉN, G. \& WARE, J. 2016. A Global Population Genetic Study of Pantala flavescens. PLoS ONE 11(3):e0148949. http://dx.doi.org/10.1371/journal.pone.0148949

VIEIRA, V. \& CORDERO-RIVERA, A. 2015. First record of Pantala flavescens from the Azores (Odonata: Libellulidae). Odonatologica 44(1/2):1-9.

VILELA, D.S., FERREIRA, R.G. \& DEL-CLARO, K. 2016. The Odonata Community of a Brazilian Vereda: seasonal patterns, species diversity and rarity in a palm swamp environment. Biosc. J. 32(2):486-495. http://dx.doi. org/10.14393/BJ-v32n2a2016-30491

VON ELLENRIEDER, N., MOLINERI, C. \& EMMERICH, D. 2009. Odonata de Uruguay: lista de especies y nuevos registros. Revista de la Sociedade Entomologica Argentina 68(1-2):227-230.

VON ELLENRIEDER, N. 2009. Micrathyria spuria. The IUCN Red List of Threatened species 2009: e.t159030A5311357. http://dx.doi.org/10.2305/ IUCN.UK.2009-2.RLTS.T159030A5311357.en

VON ELLENRIEDER, N. 2012. The levis-group of Orthemis revisited: A synopsis including a synonymy and description of six new species of Orthemis from South America (Odonata: Libellulidae). Intl. J. Odonatology 15(3):115-207. http://dx.doi.org/10.1080/13887890.2012.688186

WASSCHER, M.T. 1990. Reproduction behaviour during heavy rainfall of Oxystigma williamsoni Geijskes in Surinam (Zygoptera: Megapodagrionidae). Notulae Odonatologicae, 3(5):79-80.

Received: 05/05/2017

Revised: 17/10/2017

Accepted: 17/11/2017

Published online: 04/12/2017 